\title{
Characterization of Semi-Interpenetrated Network Alginate/Gelatin Wound Dressing Crosslinked at Sol Phase
}

\author{
Dian Pribadi Perkasa ${ }^{1, *}$, Erizal ${ }^{1}$, Tri Purwanti ${ }^{2}$, and Alva Edy Tontowi ${ }^{3}$ \\ ${ }^{1}$ Department of Radiation Processing, Center for Application of Isotopes and Radiation, National Nuclear Energy Agency, \\ Jl. Lebak Bulus Raya No. 49 Pasar Jumat, Jakarta Selatan 12070, Indonesia \\ ${ }^{2}$ Department of Work Safety and Mining Installation, Center for Nuclear Ore Technology, National Nuclear Energy Agency, \\ Jl. Lebak Bulus Raya No. 09 Pasar Jumat, Jakarta Selatan 12440, Indonesia \\ ${ }^{3}$ Department of Mechanical and Industrial Engineering, Faculty of Engineering, Universitas Gadjah Mada, \\ Jl. Teknika Utara, Yogyakarta 55281, Indonesia
}

Received June 6, 2017; Accepted January 24, 2018

\begin{abstract}
Gel contraction of alginate during ionic crosslinking at sol phase was reduced by blending with gelatin solution due to intermolecular interaction and chain entanglement. The semi-interpenetrated network (semi-IPN) of wound dressing hydrogels were prepared by overlaid alginate/gelatin blend with $1.0 \%$ (w/w) $\mathrm{CaCl}_{2}$ solution under ambient temperature for $2 \mathrm{~h}$. Results showed that gel contraction was significantly reduced with increasing gelatin content i.e. from $40.5 \pm 5.8 \%$ for pure alginate to as low as $5.8 \pm 1.2 \%$ for alginate/gelatin of $1: 7(\mathrm{w} / \mathrm{w})$. It seems that gelatin successfully inhibited alginate chains mobility during their network re-arrangement by a $\mathrm{Ca}^{2+}$ cation. The FTIR spectra of hydrogels showed a combination of characteristic vibration of alginate and gelatin. Increasing gelatin content also significantly improved elasticity and tensile strength at break of dried hydrogels. Swelling kinetics of dried hydrogels were fitted with Schott's second-order power-law model. Increasing gelatin fraction increased the swelling rate while decreased the swelling at equilibrium. Their absorptive capacity was of the interval for management of moderate to heavily exudating wound.
\end{abstract}

Keywords: alginate/gelatin; wound dressing; gel contraction; swelling kinetics; biomedical engineering

\section{ABSTRAK}

Kontraksi gel alginat selama reaksi ikatan silang secara ionik pada fase sol dapat direduksi pada campuran alginat/gelatin sebagai akibat interaksi antarmolekular dan pertautan antar rantai. Hidrogel pembalut luka dengan jaringan polimer semi-interpenetrasi (semi-IPN) tersebut diperoleh dengan menuangkan larutan $\mathrm{CaCl}_{2} 1,0 \%$ (b/b) di atas campuran alginat/gelatin pada suhu udara ambien selama 2 jam. Hasil menunjukkan bahwa kontraksi gel berkurang secara signifikan dengan meningkatnya kadar gelatin yaitu 40,5 \pm 5,8\% pada Ca-alg menjadi 5,8 $\pm 1,2 \%$ pada alginat/gelatin 1:7 (b/b). Spektrum hidrogel merupakan kombinasi vibrasi karakteristik alginat dan gelatin. Peningkatan kadar gelatin juga mampu meningkatkan elastisitas dan kekuatan tarik putus hidrogel kering. Kinetika swelling hidrogel mengikuti model Schott power-law orde dua. Peningkatan kadar gelatin meningkatkan laju swelling namun mereduksi kapasitas swelling pada kondisi ekuilibrium. Kapasitas absorpsi hidrogel tersebut dalam interval nilai untuk manajemen luka bereksudat medium hingga berat.

Kata Kunci: alginat/gelatin; pembalut luka; kontraksi gel; kinetika swelling; teknik biomedis

\section{INTRODUCTION}

Alginate is a natural polysaccharide extracted from Phaeophyceae, a brown algae family. It is a biomaterial that has numerous applications in biomedical engineering due to its excellent biocompatibility and biodegradability [1-2]. Among its application, alginate hydrogel is widely used by the clinicians as a primary wound dressing. The alginate-based hydrogel has been known for its ability to create and maintain a wound moist environment which improves the healing process $[1,3]$. Alginate also accelerates the healing process by activating macrophage to produce TNF which initiates inflammatory signals [4].

Alginate hydrogel for biomedical application is usually obtained by crosslinking of sodium alginate using divalent cation such as $\mathrm{Ca}^{2+}$ from calcium salt [23]. Ion exchange between $\mathrm{Na}^{+}$from sodium alginate with $\mathrm{Ca}^{2+}$ from $\mathrm{CaCl}_{2}$ solution occurs during the diffusion of the $\mathrm{Ca}^{2+}$ ion. The tilted-egg box model

* Corresponding author.

Email address : dpribadi@batan.go.id 
proposed that the crosslinking of alginate with divalent cations starts by the interaction of one calcium ion with the carboxyl groups of the monomeric guluronic acid unit from two different alginate chains. However, these dimers are not parallel to each other, but almost perpendicular to each other. Furthermore, they form intercluster associated multimers which constitute a 3D network of fully crosslinked insoluble calcium alginate [5].

Crosslinking of alginate with $\mathrm{Ca}^{2+}$ cation is usually conducted by immersing dried alginate membrane in calcium salt solution [6]. Alginate may also ionically be crosslinked at sol phase by pouring calcium salt solution overlayed alginate solution [7], dialysis in a gelling bath containing calcium salt solution [8], and slow release of a $\mathrm{Ca}^{2+}$ ion from calcium-gluconolactone complex [9]. Crosslinking in sol phase may shorten the fabrication process of wound dressing by eliminating the drying step of the pre-crosslinked membrane. However, severe gel contraction occurs during crosslinking at sol phase due to the free mobility of alginate chains to form a dense $3 D$ network [7].

Gelatin is a biocompatible hydrophilic biomaterial that has been widely used in the synthesis of wound dressing $[3,10]$. Gelatin provides immediate homeostasis as well as prevents wound contracture and contour deformities associated with conventional wound healing [11]. Miscibility of alginate and gelatin blend have been reported [3,12-13]. In this study, we would like to reduce the gel contraction during sol/gel transition of alginate hydrogel by blending the film forming solution with gelatin. The ionic crosslinking using $\mathrm{CaCl}_{2}$ solution resulted in a semi-IPN hydrogels matrix. Effects of gelatin content on gel contraction were evaluated, while the properties of hydrogels related to their application as wound dressing were characterized.

\section{EXPERIMENTAL SECTION}

\section{Materials}

Materials used in this research were sodium alginate purchased from Leyoung Int. Ltd. (lot no. 150113) and commercial bovine gelatin type B. Sodium chloride (Merck), calcium chloride dihydrate (Merck), and potassium bromide (Merck) were of analytical grade. Water used in this research was deionized water.

\section{Instrumentation}

The rheological property of alginate and gelatin were measured using a rotational viscometer (model DV-E, Brookfield). The infrared spectra were recorded using an FTIR spectrophotometer (model Prestige-21, Shimadzu). The tensile strength of dried hydrogels was tested using a universal testing machine (model Strograph R1, Toyoseiki). The weight of dried hydrogels during the swelling test was determined using an analytical balance (model AUW320, Shimadzu).

\section{Procedure}

\section{Rheological measurement}

Based on ASTM D2858-16 [14], the intrinsic viscosity $\left(\left[\eta_{\mathrm{sp}}\right]\right)$ of the polymer solution is determined based on kinematic viscosity ( $\eta$ ) using Ubbelohde viscometer. However, the [ $\left.\eta_{s p}\right]$ of alginate and gelatin in this study were roughly approximated based on rheological measurement. Rheological property in term of dynamic viscosity $(\mu)$ was determined by a rotational viscometer (type DV-E, Brookfield). The $\mu$ of $\mathrm{Na}$-alg was measured at $25^{\circ} \mathrm{C}$ using $0.1 \mathrm{M}$ sodium chloride as its solvent based on modified ASTM F2064-14 [15], while the viscosity of gelatin was measured at $25^{\circ} \mathrm{C}$ using water as its solvent [16]. Both polymers were prepared at five levels concentration i.e. 0.2, 0.4, 0.6, 0.8 , and $1.0 \mathrm{~g} / \mathrm{dl}$. The $\mu$ of the solution was converted to $\eta$ using Eq. 1.

$\eta=\mu / \rho$

where $\rho$ is a specific weight of solution at a defined temperature. Reported values were the average of five replications.

The $\left[\eta_{\text {sp }}\right]$ of each polymer was calculated using Huggins-Kraemer methods [14]. The value of $\eta$ was used to determine its relative viscosity $\left(\eta_{r}\right)$, specific viscosity $\left(\eta_{\mathrm{sp}}\right)$, reduced viscosity ( $\left.\eta_{\text {red }}\right)$, and an inherent viscosity ( $\eta_{\text {inh }}$ ) using Eq. 2-5.

$\eta_{\mathrm{r}}=\eta / \eta_{0}$

$\eta_{\mathrm{sp}}=\frac{\eta-\eta_{0}}{\eta_{0}}=\eta_{\mathrm{r}}-1$

$\eta_{\text {red }}=\eta_{\text {sp }} / \mathrm{C}$

$\eta_{\text {inh }}=\ln \eta_{\mathrm{r}} / \mathrm{C}$

where $\mathrm{C}$ is a concentration of polymer in solution. The value of $\left[\eta_{s p}\right]$ is the intercept of the plot line of Huggins and Kraemer equations at zero concentration. Huggins and Kraemer equation was defined as Eq. 6-7.

$\left[\eta_{\mathrm{sp}}\right]=\left(\eta_{\mathrm{sp}} / \mathrm{C}\right)_{\mathrm{c} \rightarrow 0}$
$\left[\eta_{\mathrm{sp}}\right]=\left(\ln \eta_{\mathrm{r}} / \mathrm{C}\right)_{\mathrm{c} \rightarrow 0}$

\section{Synthesis of alginate/gelatin hydrogels}

The semi-IPN alginate/gelatin hydrogels were made by blending $2.0 \%(\mathrm{w} / \mathrm{v})$ alginate solution with gelatin solution at equal volume, then crosslinked with 
$2.0 \%(w / v) \mathrm{CaCl}_{2}$ solution at sol phase under ambient temperature. A $100 \mathrm{~mL}$ of $2.0 \%(\mathrm{w} / \mathrm{v})$ alginate solution was prepared by dissolving sodium alginate powder in water at ambient temperature under continuous stirring. A $100 \mathrm{~mL}$ of gelatin solution was prepared by dissolving gelatin powder in water at a temperature of $60^{\circ} \mathrm{C}$ under continuous stirring. The gelatin solution was prepared at three level concentration to obtain final alginate/gelatin fraction of $1: 0,1: 3,1: 5$, and $1: 7(w / w)$. A $200 \mathrm{~mL}$ of $1.0 \%$ $(w / v)$ alginate solution was set as control.

Each of $12 \mathrm{~mL}$ of the film-forming blend was poured into $12.0 \times 7.8 \times 4.0(\mathrm{l} \times \mathrm{w} \times \mathrm{h}) \mathrm{cm}^{3}$ propylene mold followed by degassing under 200 mbar vacuum at ambient temperature overnight. At sol phase, each of molded solution was overlaid with a $25 \mathrm{~mL}$ of $1.0 \%(\mathrm{w} / \mathrm{v})$ $\mathrm{CaCl}_{2}$ solution for $2 \mathrm{~h}$ to allow for crosslinking of alginate. Subsequently, hydrogels were formed and removed from the molds. The excess of the $\mathrm{Ca}^{2+}$ ion within alginatebased hydrogels was removed through a triple washing with water. Then, hydrogels were dried at room temperature until a constant weight was obtained.

\section{Gel contraction measurement}

Contraction of hydrogels during crosslinking and drying was determined. The contraction was determined as a percent proportion of surface area $\left(\mathrm{I} \times \mathrm{w}, \mathrm{cm}^{2}\right)$ of each hydrogel/dried membrane $\left(A_{t}\right)$ and surface area of propylene mold $\left(A_{0}\right)$. Firstly, samples and propylene mold were scanned using a commercial scanner to obtain their digital image. Each digital image was processed using ImageJ (version 1.50i, Wayne Rasband) software to measure the surface area. The gel contraction was calculated using Eq. 8.

Contraction $(\%)=\frac{A_{t}}{A_{0}} \times 100$

\section{Fourier Transform Infrared (FTIR) spectroscopy}

Dried hydrogels were characterized using FTIR spectrophotometer (Prestige-21, Shimadzu). The FTIR spectra were recorded in the range $4000-400 \mathrm{~cm}^{-1}$ at a resolution of $2 \mathrm{~cm}^{-1}$ and sample scans of 20 times. Each spectrum was collected at room temperature using $\mathrm{KBr}$ crystal as standard background.

\section{Tensile test}

Tensile properties of dried hydrogels were determined based on modified ASTM standard D882-12 [17]. Tensile tests were performed using the universal testing machine (Strograph R1, Toyoseiki) with a maximal load capacity of $100 \mathrm{~kg}$. Each sample was cut into dumbbell shape specimen using standard dumbbell cutter ASTM D1822-L. The thickness of the specimen was measured using dial thickness gauge (No. 2050-08, Mitutoyo). Grip separation was set at $5 \mathrm{~cm}$, while crosshead speed was set at $10 \mathrm{~mm} / \mathrm{min}$. Tensile strength at yield $\left(\sigma_{B}\right)$ and modulus elasticity $(E)$ was calculated using Eq. 9-10.

$$
\begin{aligned}
& \sigma_{B}(M P a)=F_{B} / A \\
& E(G P a)=\frac{\sigma_{2}-\sigma_{1}}{\varepsilon_{2}-\varepsilon_{1}}
\end{aligned}
$$

where $F_{B}$ is a force applied at the break, expressed in Newton; $A$ is the initial cross-section area of the specimen, expressed in $\mathrm{mm}^{2} ; \sigma_{1}$ and $\sigma_{2}$ corresponding to $\varepsilon_{1 / \varepsilon_{2}}$ respectively are the tensile strengths corresponding to their elongations at any point within the elastic region. Six specimens were tested for each sample.

\section{Swelling behavior}

The free swell absorptive capacity of dried hydrogels was determined gravimetrically based on what is described in BS EN 13726-1:2002 [18] section 3.2 with modification. A $5 \times 5 \mathrm{~cm}^{2}$ was prepared and its weight was recorded $\left(\mathrm{W}_{0}\right)$. Then it was put into a Petri dish $(9.0 \pm 0.5 \mathrm{~cm}$ in diameter) containing $8 \mathrm{~mL}$ test solution $A$ that was warmed to $37 \pm 1{ }^{\circ} \mathrm{C}$. As described in BS EN 13726-1:2002 [18], test solution A consists of sodium chloride and calcium chloride solution with 142.0 and $2.5 \mathrm{mmol}$ of sodium and calcium ions, respectively. After $30 \mathrm{~min}$, the weight of the sample was recorded $\left(\mathrm{W}_{\mathrm{t}}\right)$. During the experiment, the dish was covered in order to minimize water loss due to evaporation. Ten times replication were applied for each treatment. Free swelling capacity was calculated using Eq. 11.

Free swell absorptive capacity $=\left(\mathrm{W}_{\mathrm{t}}-\mathrm{W}_{0}\right) / \mathrm{W}_{0}$

Dynamic swelling of dried hydrogels was characterized at the similar condition with free absorptive capacity measurement, except for sample size of $2.5 \times 2.5 \mathrm{~cm}^{2}$ and volume of the test solution A at $100 \mathrm{~mL}$. The weight of swelling sample $\left(\mathrm{W}_{\mathrm{t}}\right)$ was measured periodically at 10, 20, 30, 60, 120, 240, 1440, and $2880 \mathrm{~min}$. Five times replication were applied for each treatment. Swelling ratio $\left(S w_{t}\right.$ in percent) at time $\mathrm{t}$ ( $\mathrm{min})$ calculated using Eq. 12.

$\mathrm{Sw}_{\mathrm{t}}(\%)=\frac{\mathrm{W}_{\mathrm{t}}-\mathrm{W}_{0}}{\mathrm{~W}_{0}} \times 100$

\section{Statistical analysis}

The effects of gelatin content on shrinkage area, tensile properties, and free swell absorptive capacity were statistically analyzed by one-way analysis of variance (One-way ANOVA). The post hoc comparison was performed with Tukey's honestly significant difference (Tukey's HSD) test in which p-values $<0.05$ are considered statistically significant. 

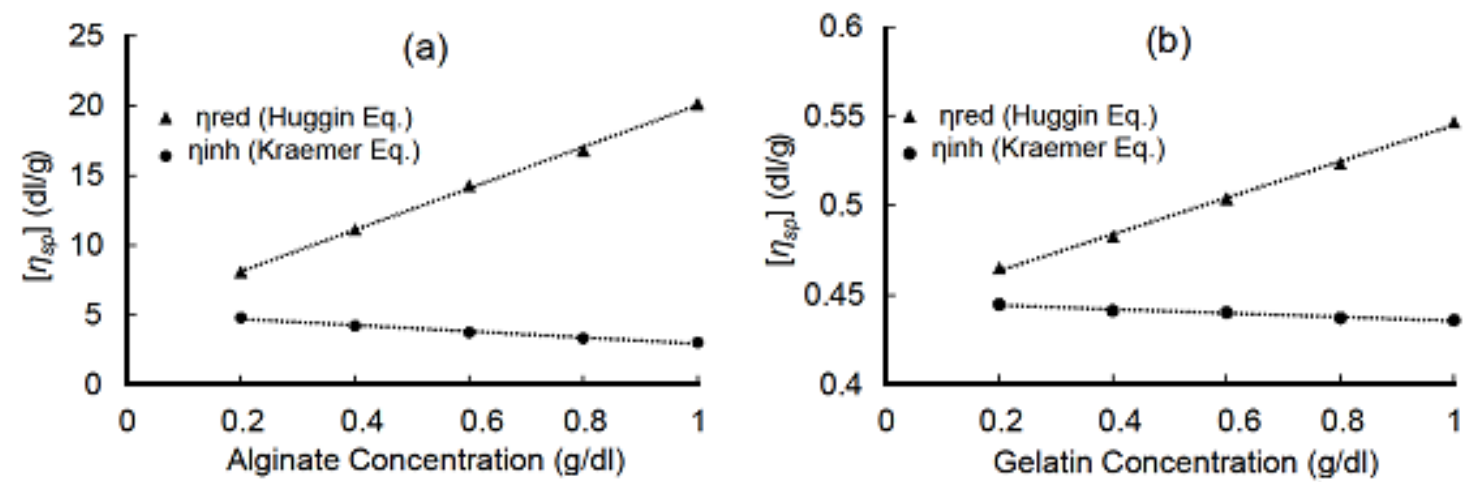

Fig 1. Double extrapolation of $\eta_{\text {red }}$ and $\eta_{\text {inh }}$ to zero for $\left[\eta_{\mathrm{sp}}\right]$ of (a) alginate and (b) gelatin

\section{RESULT AND DISCUSSION}

\section{Viscosity of Polymers}

The intrinsic viscosity is given by the ordinate intercept of double extrapolation plots of $\eta_{\text {red }}$ over $C$ and $\eta_{\text {inh }}$ over C. Fig. 1 shows this kind of plot for alginate and gelatin. Based on Fig. 1, $\left[\eta_{\mathrm{sp}}\right]$ of alginate and gelatin are about 5.16 and $0.44 \mathrm{~g} / \mathrm{mL}$, respectively. Viscosityaverage molecular weight $\left(\mathrm{M}_{\mathrm{v}}\right)$ was determined based on their $\left[\eta_{\text {sp }}\right]$ using the corresponding Mark-Houwink equation:

$\left[\eta_{\mathrm{sp}}\right]=\mathrm{K} \cdot \mathrm{M}_{\mathrm{v}}^{\mathrm{a}}$

where $\mathrm{K}$ and $\mathrm{a}$ are the Mark-Houwink constants. Their values are $\mathrm{K}=7.30 \times 10^{-3} \mathrm{dl} / \mathrm{g}$ and $\mathrm{a}=0.92$ for alginate in $0.1 \mathrm{M}$ sodium chloride at $20^{\circ} \mathrm{C}$ [19], while $\mathrm{K}=1.66 \mathrm{x}$ $10^{-5} \mathrm{dl} / \mathrm{g}$ and $\mathrm{a}=0.885$ for gelatin in water at $25^{\circ} \mathrm{C}$ [16]. Based on the calculation, the $M_{v}$ values of alginate and gelatin were at about $1.86 \times 10^{5}$ and $9.97 \times 10^{4} \mathrm{Da}$, respectively.

\section{Gel Contraction}

The semi-IPN alginate/gelatin hydrogels wound dressing have been successfully synthesized by crosslinking with a $\mathrm{CaCl}_{2}$ solution at sol phase. Hydrogels are flexible and transparent. Within the matrix, gelatin chains penetrate within the 3D alginate network. Similar to previous reports [7-8], gel contraction is observed in sol/gel transition system, as shown in Fig. 2. Pure alginate hydrogels are severely contracted at about $40.45 \pm 5.82 \%$. By blending with gelatin, gel contraction is significantly $\left(\mathrm{F}_{(3,19)}=69.751, \mathrm{p}=0.000\right)$ reduced to as low as $5.8 \pm 1.2 \%$ for semi-IPN hydrogels at alginate/gelatin of $1: 7(\mathrm{w} / \mathrm{w})$. We suggest that reduction of gel contraction is caused by the inhibition of free mobility of alginate chains by gelatin chains during $\mathrm{Ca}^{2+}$ coordinated network arrangement. The inhibition possibly related to the intermolecular interaction and chain entanglement between alginate and gelatin chains in the film forming a blend. A previous study [7] have reported

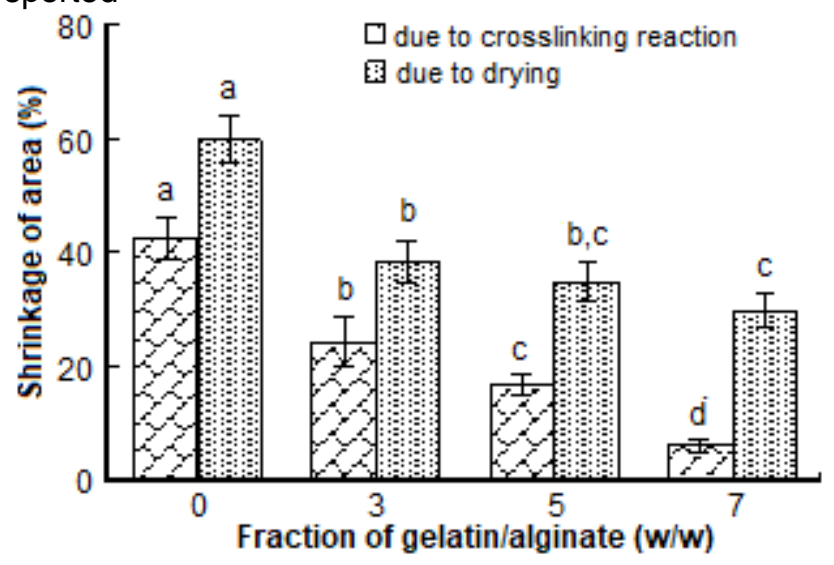

Figure 2. Effect of gelatin content on the contraction of hydrogels. Note that different letter in the same category means significantly different

the suppression of contraction of alginate hydrogels by blending with another polymer. Yajima et al. [7] have blended precursor $1.5 \%(\mathrm{w} / \mathrm{v})$ alginate solution with polypropylene glycol alginate (PGA), a non-gelling ester derivative of alginate. Gel contraction was reduced from $65 \%$ for pure alginate to about $10 \%$ at alginate/PGA ratio of $1: 2(\mathrm{w} / \mathrm{w})$. For alginate/gelatin blend, additional treatment is needed to reduce the gel contraction further such as crosslinking at gel phase by thermal treatment.

Drying by evaporation leads to the transition of hydrogels matrix from a rubbery state to a glassy state. This process also caused gel contraction. As shown in Fig. 2, gel contraction is significantly $\left(F_{(3,19)}=44.369\right.$, $p$ $=0.000)$ reduced at higher gelatin fraction. Gel contraction is at $57.91 \pm 5.76 \%$ for pure alginate, which decreases to $29.72 \pm 3.18 \%$ for alginate/gelatin membrane of $1: 7(\mathrm{w} / \mathrm{w})$. However, the lowest contraction value is still too high. Freeze-drying treatment may ideally solve this problem, but it will significantly increase production-cost and processing time. 


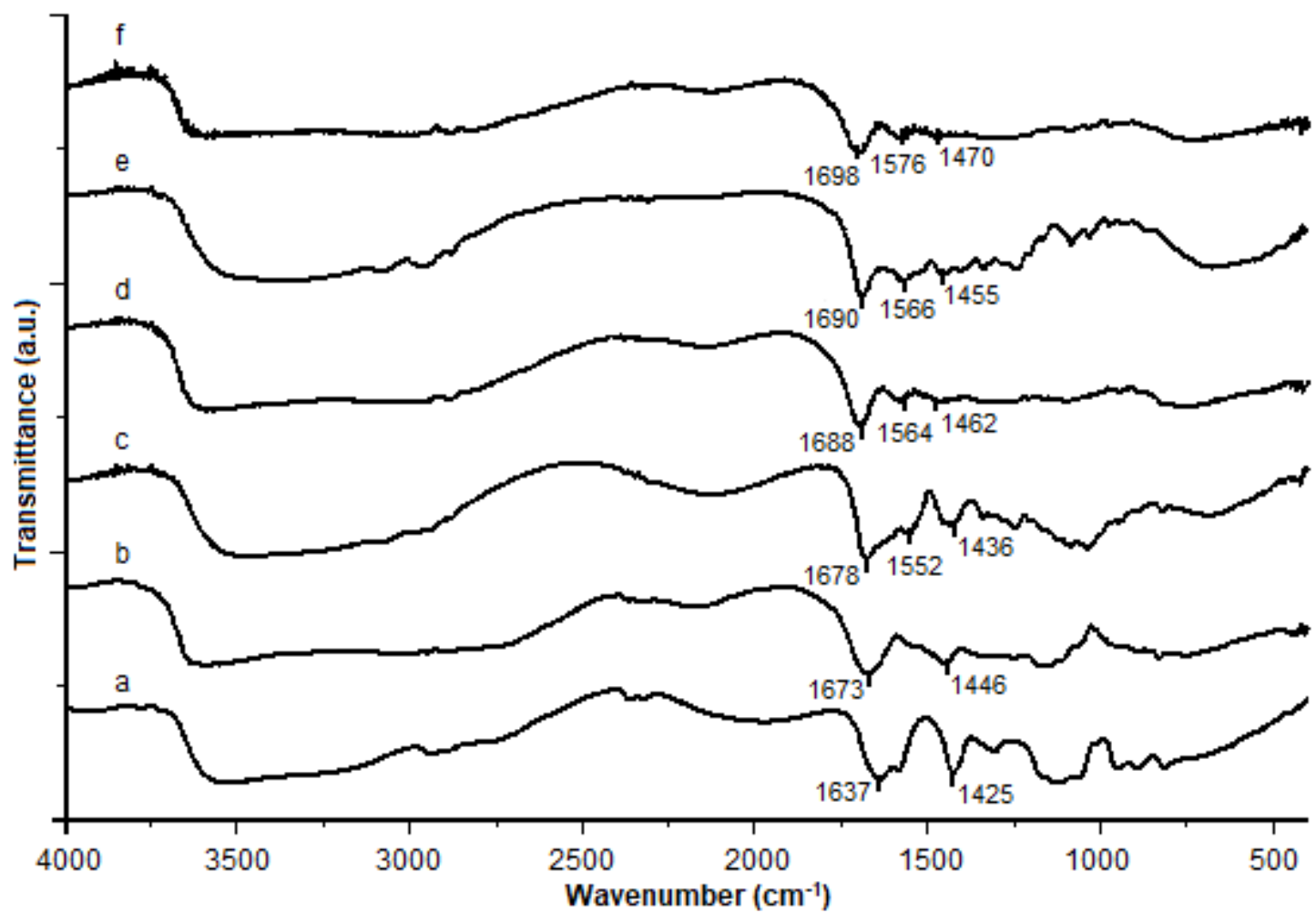

Fig 3. FTIR transmittance spectra of (a) sodium alginate, (b) calcium alginate, alginate/gelatin of (c) 1:3, (d) 1:5, and (e) $1: 7(w / w)$ as well as $(f)$ gelatin hydrogels, respectively

\section{FTIR Spectroscopy}

Characteristic FTIR bands of alginate arise from hydroxyl and carboxyl groups of $\beta$ - $D$-mannuronic acid and $\alpha$ - $L$-guluronic acid residues [20-21]. Therefore, a similar pattern is observed for FTIR spectra of sodium and calcium alginate, as shown in Fig. 3. Broadening peaks around $3800-3000 \mathrm{~cm}^{-1}$ represent the $\mathrm{O}-\mathrm{H}$ stretching band, while peaks within region 1200-960 are related to skeletal vibration of pyranose ring. The asymmetric stretching vibration of carboxylate anion is at 1637 and $1425 \mathrm{~cm}^{-1}$ for sodium alginate, which are redshifted to 1637 and $1446 \mathrm{~cm}^{-1}$ in calcium alginate. The red-shift indicates the occurrence of ion exchange process in which the weak bond between $\mathrm{COO}^{-}$anion of alginate with $\mathrm{Na}^{+}$cation is replaced by a stronger bond with $\mathrm{Ca}^{2+}$ cation [3]. The hydroxyl and carboxyl groups of alginate are the reason for a highly hydrophilic nature of the hydrogel. This implies that alginate hydrogel dressing does not stick to the wound, highly facilitating the change of dressing by causing less discomfort to the patient [1-2]. However, the cell does not attach to its surface due to its hydrophilicity [22].

The polypeptide chain of gelatin gives characteristic bands originated from amide bonds among their amino acids residue [10]. As shown in Fig. 3, amide I band is observed at $1698 \mathrm{~cm}^{-1}$ which correspond to
$\mathrm{C}=\mathrm{O}$ stretching vibration. Amide II band is observed at $1576 \mathrm{~cm}^{-1}$ which arise from a combination of $\mathrm{C}=\mathrm{O}$ stretching and $\mathrm{NH}$ bending vibration. The band around $1470 \mathrm{~cm}^{-1}$ is associated with deformation vibration of the free methyl group of amino acid residues [10,23]. Amide group of gelatin is important for biomedical application as they provide a ligand for cell attachment and proliferation [22].

The FTIR spectra blend hydrogels showed characteristic vibration of both alginate and gelatin, as shown in Fig. 3. The $\mathrm{COO}^{-}$anions asymmetric vibration of alginate and amide I of gelatin are fused which indicate the good miscibility among polymers. Additional peak to alginate spectra was observed at $1600-1500 \mathrm{~cm}^{-1}$ which associates to amide II vibration. The peak and asymmetric vibration of carboxylate anion are red-shifted to higher wavenumber as increasing gelatin content.

Additional functional groups from gelatin potentially provide better biological activity of the dressing. Wound healing is a dynamic process of replacing devitalized and damaged cellular structures and tissue layers [1,11]. A previous report $[2,22]$ showed that the more viable cells with intact nuclei and cell membranes were found within alginate/gelatin matrix as compare with pure alginate, in which the number of adherent cells increases with increasing gelatin 

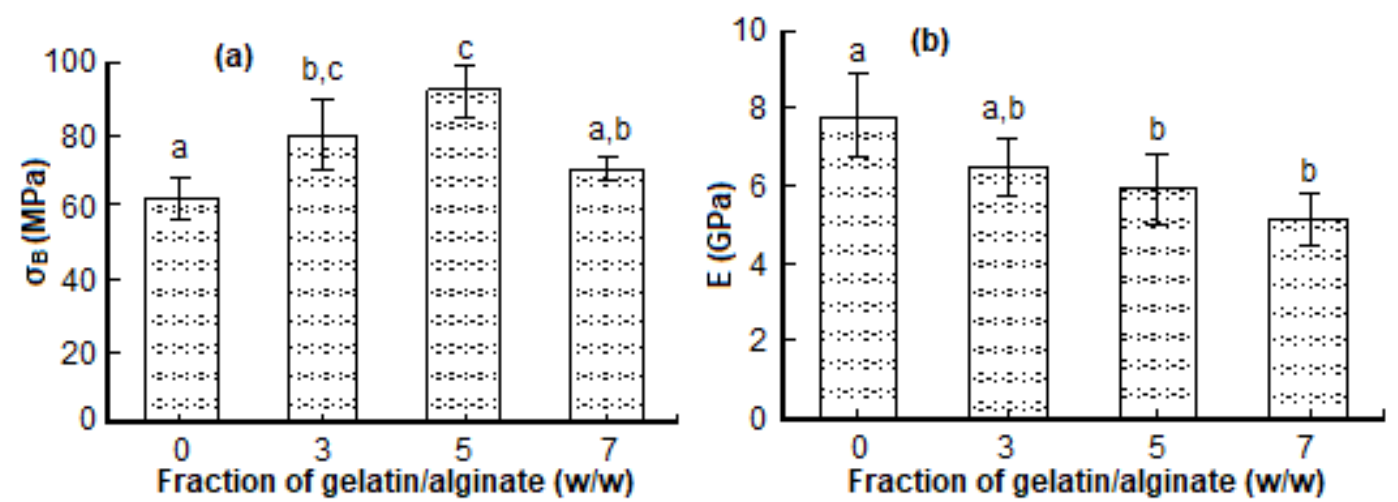

Fig 4. (a) Tensile at break $\left(\sigma_{B}\right)$ and (b) modulus elasticity (E) of hydrogels. Note that different letter in the same category means significantly different

gelatin content. Thus, blend hydrogels may potentially accelerate the healing process. However, alginate/gelatin hydrogels may be sticky to the wound with increasing cells-material interaction. Primary wound dressing requires changing over certain periods, therefore we suggest application of alginate/gelatin hydrogels wound dressing as a bioactive tissue regeneration template.

\section{Tensile Properties}

As shown in Fig. 4, increasing gelatin content significantly increase elasticity $\left(F_{(3,19)}=7.992, p=0.002\right)$ and tensile strength $\left(F_{(3,19)}=16.931, p=0.000\right)$ of dried hydrogels. Increasing elasticity, presented as lower modulus elasticity (E) value in Fig.4b, means that less $\mathrm{Ca}^{2+}$ coordinated junction point is formed due to the blending with gelatin. This result also evidenced the inhibition of free mobility of alginate chains by gelatin chains during $\mathrm{Ca}^{2+}$ coordinated network arrangement. Based on Fig. $4 a$, increasing elasticity was interestingly accompanied by increasing tensile strength which reached optimum at about $91.8 \pm 7.20 \mathrm{MPa}$ for alginate/gelatin fraction of $1: 5(\mathrm{w} / \mathrm{w})$. It seems that the decreased in the number of $\mathrm{Ca}^{2+}$ coordinated junction point is compensated by intermolecular interaction due to good miscibility of alginate/gelatin binary blend.

\section{Swelling Behavior}

Wound exudate is known to contain a proteolytic enzyme which has the capacity to damage wound bed, degrading the extracellular matrix and growth factors, and also causing peri-wound skin problems. Therefore, wound dressing ability to absorb excess wound exudate is critical to accommodate wound healing process $[1,24-$ 25]. Based on BS EN 13726-1:2002 [18], the absorbance of wound dressing without external pressure is measured as a free swell absorptive capacity. The free swell absorptive capacity of the blends hydrogels

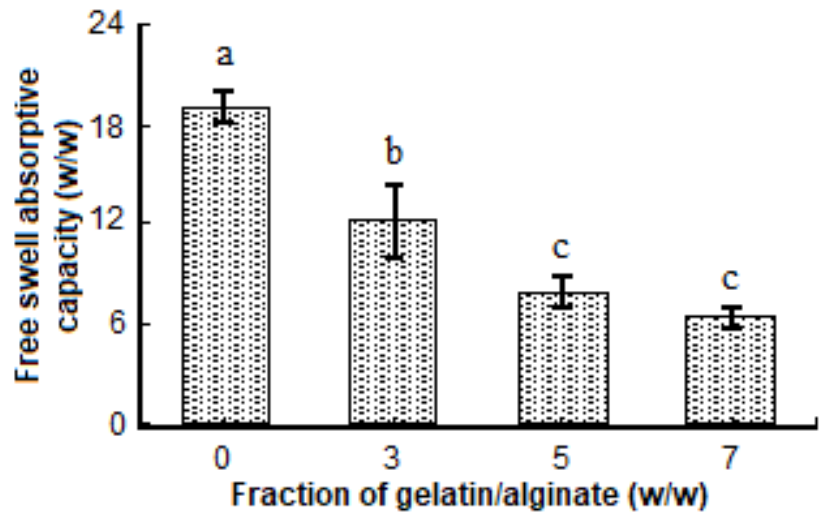

Fig 5. The free swell absorptive capacity of hydrogels. Note that different letter in the same category means significantly different

was shown in Fig. 5.

Based on Fig. 5, increasing gelatin content significantly $\left(F_{(3,19)}=86.372, p=0.000\right)$ reduce the free swell absorptive capacity of hydrogels from $19.02 \pm$ $1.01 \mathrm{~g} / \mathrm{g}$ for pure alginate to $6.50 \pm 0.69 \mathrm{~g} / \mathrm{g}$ for alginate/gelatin membrane of $1: 7(\mathrm{w} / \mathrm{w})$. Based on Uzun et al. [25], these values are in the interval of fluid handling capacity of commercial wound dressings in the UK, which is at an interval of $3.54 \pm 0.2$ to $19.07 \pm$ $2.1 \mathrm{~g} / \mathrm{g}$. Compared to their results, the lowest absorptive capacity for alginate/gelatin fraction up to $1: 7(\mathrm{w} / \mathrm{w})$ at $6.50 \pm 0.69 \mathrm{~g} / \mathrm{g}$ is comparable to the performance of $\operatorname{CombiDERM}^{\circledR}$ at $6.80 \pm 0.7$ that is intended for management of moderately to the heavily exudating wound.

Dried hydrogels absorb the solvent immediately after immersion due to external pressure applied by the solvent. As shown in Fig. 6, the swelling of pure alginate and alginate/gelatin hydrogels occurred rapidly within first $30 \mathrm{~min}$ of immersion. Uptake of simulated wound fluid slows down after $1 \mathrm{~h}$ immersion. Swelling of hydrogels does not change significantly from the fourth hour until the end of the measurement. These 
conditions represent the equilibrium swelling pressure between two opposing tendencies: the ordinary gain in entropy resulting from the mixing of polymers and the solvent, and the decrease in entropy due to the expansion of the network [8].

To observed the rate of swelling, dynamic swelling data in Fig. 6 are mathematically modeled using firstorder power-law kinetics [26-27] using Eq. 14-15.

$\mathrm{Sw}_{\mathrm{t}} / \mathrm{Sw}_{\mathrm{eq}}=\mathrm{kt}^{\mathrm{n}}$

$\ln \left(\mathrm{Sw}_{\mathrm{t}} / \mathrm{Sw}_{\mathrm{eq}}\right)=\ln \mathrm{k}_{1}+\mathrm{nlnt}$

where $k_{1}$ is a constant incorporating structural and geometrical characteristic of samples and $n$ is the diffusional exponent that indicates the mechanism of solvent diffusion. As shown in Fig. 7a, the In $\mathrm{t}$ vs In $\left(\mathrm{Sw}_{\mathrm{t}} / \mathrm{Sw}_{\mathrm{weq}}\right)$ graphs of the dynamic swelling data didn't fit linear trend line. Based on previous studies $[8,28]$, these results indicate that the rate of swelling is not directly proportional to the uptake of swelling medium at any given t time. Thus, the swelling behavior of hydrogels is not only controlled by diffusion. Therefore, Schott's second-order power-law kinetic is applied using Eq. 16 $[8,28]$.

$\frac{\mathrm{t}}{\mathrm{Sw}_{\mathrm{t}}}=\frac{1}{\mathrm{~S} \mathrm{w}_{\mathrm{eq}}} \cdot \mathrm{t}+\frac{1}{\mathrm{k}_{2} \cdot \mathrm{Sw}_{\mathrm{eq}}^{2}}$

where $k_{2}$ is the second-order swelling rate constant. As shown in Fig. $7 b$, the $t / S w_{t}$ vs $t$ graphs of the dynamic swelling data fitted linear trend-line. Further, the $\mathrm{Sw}_{\mathrm{eq}}$ and $k_{2}$ of each membrane were calculated using Eq. 1718.

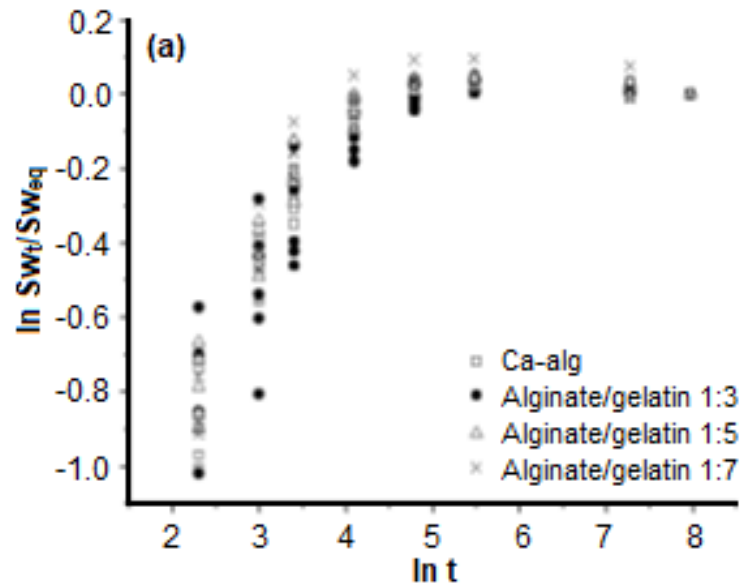

$\mathrm{Sw}_{\mathrm{eq}}=1 /$ slope

$\mathrm{k}_{2}=\frac{1}{\text { Intercept } \times \mathrm{Sw}_{\mathrm{eq}}^{2}}$

where slope and intercept are obtained from regression equation of linear fit in Fig. 7b. Fitting parameters of Schott's second order power-law kinetics are summarized in Table 1.

Based on Fig. 7b, swelling behaviors of all hydrogels follow a second-order kinetic. The results

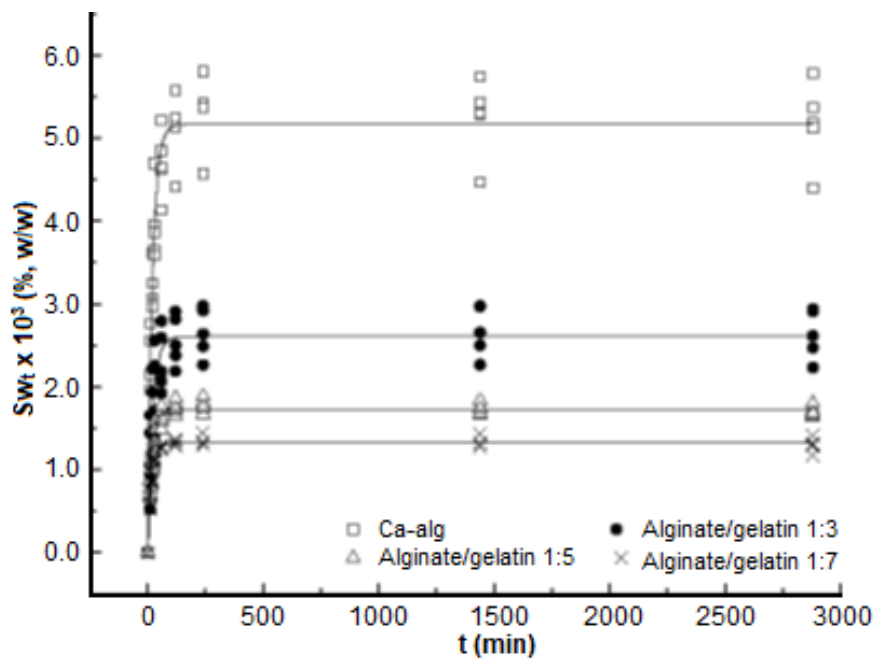

Fig 6. Dynamic swelling of hydrogels

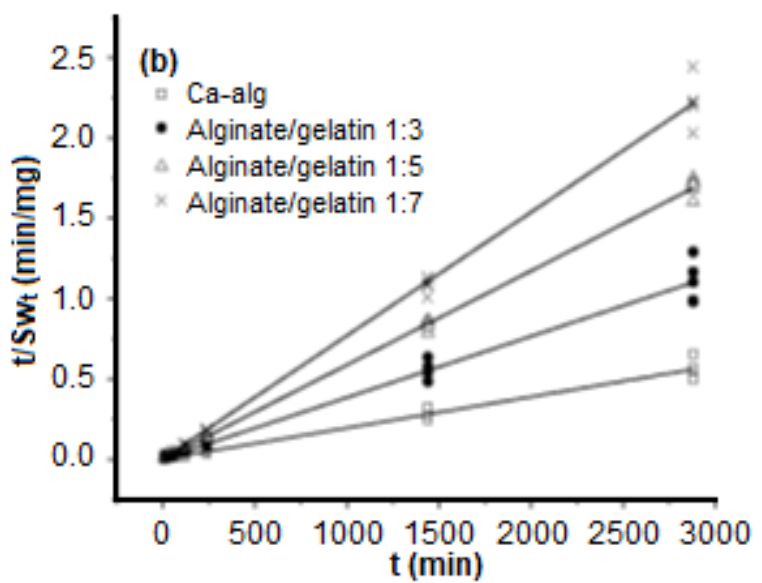

Fig 7. (a) First-order and (b) second-order swelling kinetics of hydrogels

Table 1. Parameters obtained from the linear fit of the second-order swelling kinetic data

\begin{tabular}{|c|c|c|c|c|c|}
\hline \multirow{2}{*}{ Composition } & \multicolumn{3}{|c|}{ Linear regression parameter } & \multirow{2}{*}{$\begin{array}{l}\text { Calculated } \\
\text { Sweq }(\mathrm{mg})\end{array}$} & \multirow{2}{*}{$\begin{array}{c}\mathrm{k} \\
\left(\mathrm{min}^{-1} \mathrm{mg}^{-1}\right)\end{array}$} \\
\hline & Slope & Intercept & R-square & & \\
\hline Alginate & $1.94 \times 10^{-4}$ & $9.37 \times 10^{-4}$ & 0.99 & $5.16 \times 10^{3}$ & $4.01 \times 10^{-5}$ \\
\hline Alginate/gelatin 1:3 & $3.81 \times 10^{-4}$ & $3.16 \times 10^{-3}$ & 0.99 & $2.62 \times 10^{3}$ & $4.62 \times 10^{-5}$ \\
\hline Alginate/gelatin 1:5 & $5.86 \times 10^{-4}$ & $1.21 \times 10^{-3}$ & 1.00 & $1.71 \times 10^{3}$ & $2.83 \times 10^{-4}$ \\
\hline Alginate/gelatin $1: 7$ & $7.68 \times 10^{-4}$ & $1.19 \times 10^{-3}$ & 1.00 & $1.30 \times 10^{3}$ & $4.97 \times 10^{-4}$ \\
\hline
\end{tabular}


indicate fast diffusion process that occurs within first 30 min is replaced by swelling stress relaxation as the principal rate-controlling factor for remaining swelling interval. Schott [28] described that the rate of swelling at any given t time for second order power-law kinetic is directly proportional to two factors. The first factor is the relative amount of unrealized uptake of swelling medium at that time $\left[\left(\mathrm{Sw}_{\text {eq }}-\mathrm{Sw}_{\mathrm{t}}\right) / \mathrm{Sw}_{\text {eq }}\right]$ which is the fractional amount of swelling capacity still available. Progressive swelling expands the amorphous domains and increases the stress on the crystalline region holding the semicrystalline network together. The stressed crystalline domain resists further swelling. Their resistance increases as the swelling become more extensive and slow down the rate. The second factor is the internal specific boundary ( $S_{\text {int }}$ ) enclosing all the sites that have not yet interact with water and swelled at a given time but that will be hydrated and swell in due course. The quantity of $S_{\text {int }}$ represents the sum of surface area enveloping every site in a given volume of the membrane that is capable of swelling but not yet done at given $t$ time $[8,28]$. This type swelling kinetics was also observed for various polymer system, such as alginate [8], gelatin [28-29], IPN of alginate/gelatin [13], polyacrylamide-co-itaconic acid/chitosan [30], and semiIPN of wheat straw cellulose-g-poly(potassium acrylate)/polyvinyl alcohol [31].

The calculated swelling at equilibrium in Table 1 and swelling measured after $4 \mathrm{~h}$ in Fig. 6 verify that all hydrogels composition reached equilibrium after $4 \mathrm{~h}$ of immersion. As shown in Table 1 , increasing gelatin content decreased the swelling at equilibrium. These results prove the existence of semi-IPN matrix of alginate/gelatin hydrogels. Related to Schott's first factor [28], penetrating gelatin chains fills the swelling site of a 3D network of alginate which reduced the given volume for swelling. Effects of gelatin content on increased diffusion rate may be related to hydrophilic nature of gelatin that facilitates solvent diffusion and hydration of an amorphous region of the semi-IPN matrix.

\section{CONCLUSION}

Severe contraction of alginate hydrogels during ionic crosslinking at sol phase is significantly reduced by blending with gelatin. We suggest that the reduction is caused by intermolecular interaction and chain entanglement with gelatin chains which inhibits the mobility of alginate chains during $\mathrm{Ca}^{2+}$ coordinated network arrangement. Blending with gelatin also significantly improve properties of semi-IPN hydrogels in term of increasing elasticity and tensile strength. For wound dressing application, blending with gelatin would provide better cell-biomaterials interaction for cells attachment and proliferation within the matrix. Increasing bioactivity of alginate/gelatin hydrogels suggests their wound dressing application not as a primary wound dressing but as a bioactive tissue regeneration template. As compared to a commercially available wound dressing, the absorptive capacity of hydrogels in this research are prospective for management of moderately to the heavily exudating wound. Swelling behavior of alginate/gelatin followed Schott's secondorder power-law kinetics. For different types of wound, wound dressing can be synthesized with appropriate the swelling at equilibrium and swelling rate which can be adjusted conveniently by controlling gelatin content.

\section{Acknowledgment}

We are thankful to Ir. Basril Abbas from BATAN Research Tissue Bank, the Republic of Indonesia who provided expertise that greatly assisted the research.

\section{REFERENCES}

[1] Madaghiele, M., Demitri, C., Sannino, A., and Ambrosio, L., 2014, Polymeric hydrogels for burn wound care: Advanced skin wound dressings and regenerative templates, Burns Trauma, 2 (4), 153161.

[2] Lee, K.Y., and Mooney, D.J., 2012, Alginate: Properties and biomedical applications, Prog. Polym. Sci., 37 (1), 106-126.

[3] Saarai, A., Kasparkova, V., Sedlacek, T., and Saha, P., 2013, On the development and characterisation of crosslinked sodium alginate/gelatine hydrogels, J. Mech. Behav. Biomed. Mater., 18, 152-166.

[4] Yang, D., and Jones, K.S., 2009, Effect of alginate on innate immune activation of macrophages, $J$. Biomed. Mater. Res. Part A, 90 (2), 411-418.

[5] Borgogna, M., Skjåk-Bræk, G., Paoletti, S., and Donati, I., 2013, On the initial binding of alginate by calcium ions. The tilted egg-box hypothesis, $J$. Phys. Chem. B, 117 (24), 7277-7282.

[6] Li, J., He, J., Huang, Y., Li, D., and Chen, X., 2015, Improving surface and mechanical properties of alginate films by using ethanol as a co-solvent during external gelation, Carbohydr. Polym., 123, 208-216.

[7] Yajima, Y., Yamada, M., Yamada, E., Iwase, M., and Seki, M., 2014, Facile fabrication processes for hydrogel-based microfluidic devices made of natural biopolymers, Biomicrofluidics, 8 (2), 24115.

[8] Davidovich-Pinhas, M., and Bianco-Peled, H., 2010, A quantitative analysis of alginate swelling, Carbohydr. Polym., 79 (4), 1020-1027.

[9] Bajpai, M., Shukla, P., and Bajpai, S.K., 2017, Enhancement in the stability of alginate gels 
prepared with a mixed solution of divalent ions using a diffusion through dialysis tube (DTDT) approach, J. Macromol. Sci. Part A Pure Appl. Chem., 54 (5), 301-310.

[10] Perkasa, D.P., Erizal, Darmawan, and Rasyid, A., 2013, Effect of gamma irradiation on mechanical and thermal properties of fish gelatin film isolated from lates calcarifer scales, Indones. J. Chem., 13 (1), 28-35.

[11] Ayvazyan, A., Morimoto, N., Kanda, N., Takemoto, S., Kawai, K., Sakamoto, Y., Taira, T., and Suzuki, S., 2011, Collagen-gelatin scaffold impregnated with bFGF accelerates palatal wound healing of palatal mucosa in dogs, J. Surg. Res., 171 (2), 247-257.

[12] Rosellini, E., Cristallini, C., Barbani, N., Vozzi, G., and Giusti, P., 2009, Preparation and characterization of alginate/gelatin blend films for cardiac tissue engineering, J. Biomed. Mater. Res. Part A, 91 (2), 447-453.

[13] Mohanan, A., and Vishalakshi, B., 2009, Swelling and diffusion characteristics of interpenetrating network films composed of sodium alginate and gelatin: Transport of Azure B, Int. J. Polym. Mater., 58 (11), 561-580.

[14] ASTM D2857-16, Standard Practice for Dilute Solution Viscosity of Polymers, 2016, ASTM International, West Conshohocken, PA.

[15] ASTM F2027-16, Standard Guide for Characterization and Testing of Raw or Starting Materials for Tissue-Engineered Medical Products, 2014, ASTM International, West Conshohocken, PA.

[16] Masuelli, M.A., 2014, Mark-Houwink Parameters for aqueous-soluble polymers and biopolymers at various temperatures, J. Polym. Biopolym. Phys. Chem., 2 (2), 37-43.

[17] ASTM D882-12, Standard Test Method for Tensile Properties of Thin Plastic Sheeting, 2012, ASTM International, West Conshohocken, PA.

[18] BS EN 13726-1:2002, Test Methods for Primary Wound Dressings. Aspects of Absorbency, 2002, British Standard Institution, London.

[19] Pamies, R., Schmidt, R.R., Martínez, M.C.L., and de la Torre, J.G., 2010, The influence of mono and divalent cations on dilute and non-dilute aqueous solutions of sodium alginates, Carbohydr. Polym., 80 (1), 248-253.

[20] Daemi, H., and Barikani, M., 2012, Synthesis and characterization of calcium alginate nanoparticles, sodium homopolymannuronate salt and its calcium nanoparticles, Sci. Iran., 19 (6), 2023-2028.

[21] Xiao, Q., Gu, X., and Tan, S., 2014, Drying process of sodium alginate films studied by twodimensional correlation ATR-FTIR spectroscopy, Food Chem., 164, 179-184.

[22] Sarker, B., Singh, R., Silva, R., Roether, J.A., Kaschta, J., Detsch, R., Schubert, D.W., Cicha, I., and Boccaccini, A.R., 2014, Evaluation of fibroblasts adhesion and proliferation on alginategelatin crosslinked hydrogel, PLoS One, 9 (9), 112.

[23] Vidal, B.C., and Mello, M.L.S., 2011, Collagen type I amide I band infrared spectroscopy, Micron, 42 (3), 283-289.

[24] Adderley, U.J., 2010, Managing wound exudate and promoting healing, Br. J. Community Nurs., 15 (3), S15-6.

[25] Uzun, M., Anand, S.C., and Shah, T., 2013, In vitro characterisation and evaluation of different types of wound dressing materials, J. Biomed. Eng. Technol., 1 (1), 1-7.

[26] Ganji, F., Vasheghani-Farahani, S., and Vasheghani-Farahani, E., 2010, Theoretical description of hydrogel swelling: A review, Iran. Polym. J., 19 (5), 375-398.

[27] Siepmann, J., and Peppas, N.A., 2001, Modeling of drug release from delivery systems based on hydroxypropyl methylcellulose (HPMC), Adv. Drug Delivery Rev., 48 (2-3), 139-157.

[28] Schott, H., 1992, Kinetics of swelling of polymers and their gels, J. Pharm. Sci., 81 (5), 467-470.

[29] Qiao, C., and Cao, X., 2014, Swelling behavior of physically cross-linked gelatin gels in varied salt solutions, J. Macromol. Sci. Part B Phys., 53 (10), 1609-1620.

[30] Martínez-Ruvalcaba, A., Sánchez-Díaz, J.C., Becerra, F., Cruz-Barba, L.E., and GonzálezÁlvarez, A., 2009, Swelling characterization and drug delivery kinetics of polyacrylamide-co-itaconic acid/chitosan hydrogels, eXPRESS Polym. Lett., 3 (1), 25-32.

[31] Liu, J., Li, Q., Su, Y., Yue, Q., and Gao, B., 2014, Characterization and swelling-deswelling properties of wheat straw cellulose based semiiPNS hydrogel, Carbohydr. Polym., 107, 232-240. 